DOI https://doi.org/10.30525/978-9934-588-81-5-1.32

\title{
PECULIARITIES OF PARENTAL ATTITUDE TO CHILDREN OF PRIMARY SCHOOL AGE WITH RECURRENT RESPIRATORY INFECTIONS
}

\author{
Kramarchuk V. V. \\ Assistant at the Department of Family Medicine \\ of the Faculty of Postgraduate Education \\ State Institution "Dnipropetrovsk Medical Academy \\ of the Ministry of Health of Ukraine" \\ Dnipro, Ukraine
}

Introduction. Respiratory diseases have long held the first place in the structure of morbidity of the population, especially children. The vast majority (about $70 \%$ ) of visits to the primary care physician are young children with a recurrent course of acute respiratory infections (ARI) [3, 4]. On the one hand, they contribute to the development of immunity, and on the other hand, they cause increased anxiety of parents, frequent visits to the doctor, excessive use of antibiotics and poor socialization due to reduced attendance at preschools and schools [2]. Over time, there is a change in the model of the «mother-child» relationship, which can play an important role in increasing the frequency and severity of ARI [1].

Materials and methods. We examined 40 children aged 6 to 10 years with recurrent ARI (main group) and 30 healthy children of the same age (control group). We conducted a follow-up examination, general clinical examinations (blood and urine tests), psychological testing using the method of diagnosing the parental relationship Varga-Stolin and determining parental anxiety using the Spielberger-Khanin questionnaire.

Results and discussion. The results of the comparison of blood and urine tests did not reveal statistically significant differences between the main and control groups. Comparing the results of the Spielberger-Khanin anxiety test in the parents of children in the main and control groups using the $t$ criterion for unrelated samples revealed a statistically significant difference $(p=0.042)$ in the rate of personal anxiety of mothers.

Table 1

\begin{tabular}{|c|c|c|}
\hline Indicator & $\begin{array}{c}\text { Children with } \\
\text { recurrent ARI (M } \pm \mathbf{m})\end{array}$ & $\begin{array}{c}\text { Healthy children } \\
\mathbf{( M \pm m )}\end{array}$ \\
\hline Reactive anxiety of the father & $35,1 \pm 1,4$ & $34,3 \pm 1,3$ \\
\hline Personal anxiety of the father & $38,5 \pm 1,5$ & $36,5 \pm 0,9$ \\
\hline Reactive anxiety of the mother & $36,5 \pm 1,4$ & $33,9 \pm 1,2$ \\
\hline Mother's personal anxiety & $42,7 \pm 1,6$ & $37,6 \pm 0,8$ \\
\hline
\end{tabular}

Spielberger-Khanin test scores in parents of children in the main and control groups 
Higher levels of personal anxiety in mothers of children in the main group may be the result of feelings about their children, contribute to neuroticism, emotional breakdowns and deteriorating family relationships.

Table 2

\begin{tabular}{|c|c|c|}
\hline Type of parental attitude & $\begin{array}{c}\text { Children with } \\
\text { recurrent ARI }\end{array}$ & Healthy children \\
\hline Adoption (father) & $9,4 \pm 0,3$ & $10,0 \pm 0,6$ \\
\hline Cooperation (father) & $6,8 \pm 0,2$ & $6,9 \pm 0,2$ \\
\hline Symbiosis (father) & $4,4 \pm 0,3$ & $4,2 \pm 0,3$ \\
\hline Authoritarianism (father) & $3,7 \pm, 0,2$ & $3,9 \pm 0,2$ \\
\hline Little loser (father) & $1,8 \pm 0,2$ & $1,9 \pm 0,2$ \\
\hline Health Concerns (Parent) & $5,0 \pm 0,3$ & $4,6 \pm 0,2$ \\
\hline Adoption (mother) & $9,7 \pm 0,3$ & $10,3 \pm 0,3$ \\
\hline Cooperation (mother) & $7,3 \pm 0,2$ & $7,1 \pm 0,2$ \\
\hline Symbiosis (mother) & $4,3 \pm 0,3$ & $2,8 \pm 0,2$ \\
\hline Authoritarianism (mother) & $3,6 \pm 0,3$ & $3,7 \pm 0,3$ \\
\hline Little loser (mother) & $3,0 \pm 0,2$ & $2,1 \pm 0,1$ \\
\hline Health concerns (mother) & $4,9 \pm 0,2$ & $4,5 \pm 0,2$ \\
\hline
\end{tabular}

Indicators of the test of parental attitude of parents of children of the main and control groups

Statistically significant differences were found in the indicators «symbiosis of mother and child» and «little loser» on the maternal side.

Conclusions. Thus, it can be stated that mothers of children with recurrent ARI have higher rates of reactive anxiety ( 42.7 vs. 37.6 in the control group), which can be caused by frequent episodes of ARI in children. The model of the relationship between mothers and children from the main group demonstrated the transition to an ineffective parenting style - «symbiosis» and «little loser», which can increase the duration of adaptation and reduce the socialization of children. Further research will include factorial and regression analysis with the expansion of the main group.

\section{References:}

1. Chernyshova L. I. Рекуррентные респираторные заболевания у детей: алгоритм действий врача (лекция) //Современная педиатрия. 2018. - №. 3. - С. 92-97.

2. Lemko O. I., Lukashchuk S. V. Рекуррентные респираторные заболевания в практике семейного врача и педиатра: главные вопросы (обзор литературы) //Запорожский медицинский журнал. - 2019. - №. 6. 
3. Fesenko M. Y. et al. Acute respiratory recurrent infections in children // Актуальні проблеми сучасної медицини: Вісник Української медичної стоматологічної академії. - 2019. - Т. 19. - №. 4. - С. 34-38.

4. Thomas M, Koutsothanasis GA, Bomar PA. Upper Respiratory Tract Infection. [Updated 2020 Jun 30]. In: StatPearls [Internet]. Treasure Island (FL): StatPearls Publishing; 2020 Jan-. Available from: https://www.ncbi.nlm.nih.gov/books/NBK532961/

DOI https://doi.org/10.30525/978-9934-588-81-5-1.33

\title{
СУЧАСНІ ПРИНЦИПИ РЕСПІРАТОРНОЇ ПІДТРИМКИ ПРИ ТЯЖКІЙ ЧЕРЕПНО-МОЗКОВІЙ ТРАВМІ
}

\author{
Кріштафор Д. А. \\ кандидат медичних наук,
}

асистент кафедри анестезіологї, інтенсивної терапї̈ та медицини невідкладних станів факультету післядипломної освіти

Д3 «Дніпропетровська медична академія

Міністерства охорони здоров'я Украӥни»

\section{Клигуненко О. М.}

доктор медичних наук,

професор кафедри анестезіології, інтенсивної терапії та медицини невідкладних станів факультету післядипломної освіти

ДЗ «Дніпропетровська медична академія

Міністерства охорони здоров'я України»

Кравець О. В.

кандидат медичних наук,

доцент кафедри анестезіології, інтенсивної терапї та медицини невідкладних станів факультету післядипломної освіти

Д3 «Дніпропетровська медична академія

Міністерства охорони здоров'я України»

\section{Схалов В. В.}

кандидат медичних наук,

доцент кафедри анестезіології, інтенсивної терапї та медицини невідкладних станів факультету післядипломної освіти

Д3 «Дніпропетровська медична академія

Міністерства охорони здоров'я Украӥни» 